\title{
Geologi-geoscience i Kobenhavn - en verden af muligheder
}

Geologi-geoscience-studerende på feltarbejde i Spanien. (Foto: Tod Waight, KU)

Af geolog og informationsansvarlig Nina Herrmann, Institut for Geografi og Geologi, Københavns Universitet

\section{Geologi-geoscience-studiet på Kø-} benhavns Universitet er for dig, der gerne vil beskæftige dig tværfagligt med naturvidenskab i et bredt perspektiv og samtidig få en samfundsanvendelig viden inden for eksempelvis olie, råstoffer, grundvand, klima og miljø - en viden, der lige nu efterspørges af arbejdsmarkedet i Danmark og i udlandet.

Geologi-geoscience-studiet er også et godt valg, hvis du er til store naturoplevelser, kan lide fordybelsen i laboratoriet, værdsætter et inspirerende studiemiljø og gerne vil have gode og fleksible jobmuligheder bagefter.

\section{Videnskab om Verden}

Geologi-geoscience er videnskaben om Jordens oprindelse, sammensætning og udvikling gennem næsten 5 mia. år. Det handler om de processer, der forandrer Jorden, og som er grundlag for vores eksistens; de største tidsrum og voldsomste kræfter, vi overhovedet kender; og om pladetektonik, jordskælv, vulkaner, mineraler, meteoritter, istider, ørkner, råstoffer, livets opståen ogmeget mere - altså om vores Verden.

\section{Samfundsrelevant viden}

Geologisk viden om Jordens opbygning, processer og ressourcer bruges overalt lokalt og globalt i forbindelse med efterforskning og udnyttelse af råstoffer, vandforsyning, forureningsbekæmpelse, miljøbeskyttelse, klimaforskning, udvikling af nye materialer, beredskab ved naturkatastrofer, ved byggeri og anlæg og lignende samfundsbærende områder.

\section{Uddannelse med oplevelser og valgfrihed} Geologi-geoscience-uddannelsen på Københavns Universitet tilbyder unikke naturoplevelser på de mange ekskursioner og feltture i Danmark og udlandet, som udgør en væsentlig del af uddannelsen på både bachelor- og kandidatniveau. Som en integreret del af undervisningen får alle studerende mulighed for at deltage i feltarbejdet på aktuelle forskningsprojekter og arbejde videre med de indsamlede resultater bagefter. Derudover består undervisningen af forelæsninger, praktiske øvelsestimer samt laboratorie- og analysearbejde, hvortil der benyttes avanceret laboratorie- og IT-udstyr. Undervisningen veksler således hele tiden mellem teoretiske og praktiske studier.

Bacheloruddannelsen i Geologi-geoscience varer 3 år og afsluttes med et selvstændigt bachelorprojekt. Fra 2. studieår og frem har du, hvad der svarer til 1 års valgfrihed, hvor du selv kan sammensætte dit uddannelsesforløb efter, hvad, du synes, er mest spændende og relevant. Du kan fx tage på udlandsophold, i virksomhedspraktik eller følge relevante kurser på andre danske uddannelsesinstitutioner. Efter bacheloruddannelsen kan du søge ind på kandidatuddannelsen, der varer to år og af sluttes med et selvstændigt projekt - specialet.

Tværfaglighed og kreative udfordringer Geologi-geoscience-studiet kombinerer ny viden og nye metoder inden for fag som biologi, fysik/geofysik, kemi/geokemi, nanoteknologi, økologi, klimatologi, m.m. Du får dermed et helhedsbillede af Jordens opbygning og udvikling samt et overblik over vores naturskabte levevilkår og tilgængelige ressourcer. Samtidig får du den filosofiske og idehistoriske baggrund for den geologiske videnskab. Geologi-geoscience er et fagområde, der konstant udfordrer din fantasi, kreativitet og tankekraft - og dine egne ideer er velkomne.

Feltarbejde og personlige kompetencer På Geologi-geoscience-studiet kommer du på mange ekskursioner og feltkurser i naturen. Her kommer du til at observere geologien i virkeligheden, og du får mulighed for at prøve teorien fra undervisningen af i praksis. Du lærer de praktiske geologiske arbejdsmetoder at kende, bl.a. hvordan man indsamler data til viderebearbejdelse derhjemme. Geologisk feltarbejde giver dig samtidig generelle kompetencer i teambuilding, praktisk problemløsning, arbejdssikkerhed samt at kunne forholde dig professionelt til naturen. Desuden får du kommunikative kompetencer i form af rapportskrivning og anden videnskabsformidling.

\section{Rejser i Danmark og udlandet}

Ekskursioner er kortere ture ud i naturen af typisk en dags varighed og foregår som

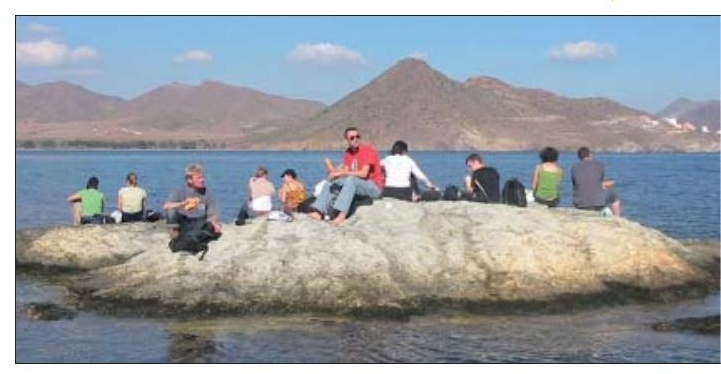

regel i Danmark eller Sydsverige. Feltkurser kan vare flere uger og foregår ofte i udlandet fx USA, Vietnam, Spanien, Norge og Sverige. Feltture går ikke altid til almindelige rejsemål, hvorfor du får mulighed for helt unikke naturoplevelser. Man arbejder sammen i teams med mulighed for socialt samvær med både studerende og undervisere.

\section{Godt studiemiljø}

Geologi-geoscience er et forholdsvis lille studium med ca. 25 optagne hvert år. Det giver et fantastisk sammenhold på tværs af årgangene og blandt studerende og undervisere og skaber en god atmosfære på studiet. Der er mange sociale og faglige arrangementer på studiet, hvor de studerende mødes med hinanden og studerende fra andre uddannelser i både København og Århus.

\section{Verden som arbejdsplads}

Geologi skaber økonomi, netværk og arbejdspladser over hele Verden. En uddannelse som geolog giver dig en verden af muligheder for ansættelse samt mange spændende og samfundsrelevante arbejdsopgaver. I Danmark ansættes geologer i den offentlige og private sektor. Offentlige ansættelser er typisk i regioner, kommuner, offentlige styrelser, universiteter samt sektorforskningsinstitutioner som fx Danmarks og Grønlands Geologiske Undersøgelse (GEUS), forskningscenter Risø og Danmarks Meteorologiske Institut (DMI). I industrien ansættes geologer i mange forskellige brancher. De største arbejdspladser for geologer er olieselskaber, entreprenørfirmaer og rådgivende ingeniørfirmaer. Et stigende antal danske geologer finder arbejde i udlandet i forbindelse med miljøorienteret udviklingsarbejde, rådgivning, i mineindustrien, i olieindustrien og på universiteter og andre forskningsinstitutioner.

\section{Info}

Find flere informationer om studiet på: www.geo.ku.dk eller direkte på: http://studieinfo.geol.ku.dk/

Kontakt studievejlederen for geofagene på www.nat.ku.dk eller på e-mail:

NAT-nsv@adm.ku.dk

Institut for Geografi og Geologi, Københavns Universitet: www.geo.ku.dk 